Хитра О. В., к.е.н., доцент

Хмельницький університет управління та права

імені Леоніда Юзькова

м. Хмельницький, Украӥна

DOI: https://doi.org/10.30525/978-9934-26-064-3-13

\title{
СИНЕРГЕТИЧНІ АСПЕКТИ ТУРИСТИЧНО-РЕКРЕАЦІЙНОЇ ДІЯЛЬНОСТІ В УМОВАХ СТАЛОГО РОЗВИТКУ ТЕРИТОРІЙ
}

Туристично-рекреаційна діяльність розгортається у нелінійному середовищі, що являє собою поєднання природних та антропогенних елементів, взаємодія яких може обумовити як сприятливі, так і негативні впливи на рекреацію. Оскільки формування рекреаційних потреб відбувається під впливом великої кількості взаємопов'язаних (а інколи й суперечливих) факторів, для розробки заходів щодо їх продуктивного задоволення також доцільно застосовувати нелінійний підхід.

Відповідно, варто погодитись з Т.Є. Кунгурцевою-Мащенко, яка вважає, що «ринкову орієнтацію курортно-рекреаційних комплексів покликані забезпечити відповідні методології, засновані на ... широкому застосуванні механізму синергетичного ефекту» [1, с. 706].

Також слушною $є$ точка зору Н.I. Моісєєвої щодо синергічної функції туризму, яка реалізується через створення різнорівневого ринку туристичних послуг, збільшення доходів населення та підвищення рівня його добробуту, а також завдяки різногалузевому взаємозв'язку за видами економічної діяльності, зокрема в інтеграційних і глобалізаційних процесах $[2$, с. 8].

У свою чергу, Т. Скоробогатова стверджує, що синергетичний ефект «створюється у логістичних сервісних системах, які оптимізують і обслуговують потоки споживачів» [3, с. 167].

М.В. Шарко і П.В. Шмулевич основним проявом синергії у бізнес-середовищі туристичної сфери пропонують вважати інформацію; сам турпродукт є проявом синергії навколишнього 
бізнес-середовища, оскільки містить блага, які формуються іншими галузями (транспорт, харчова промисловість, сфера послуг тощо), а інформація при цьому стає сполучною ланкою всіх супутніх благ [4, с. 88]. Створення інфраструктури туризму розглядається як етап активізації синергетичних можливостей бізнес-середовища, що сприяє сприйняттю споживачем турпродукту інформації і досвіду приймаючої системи у чітко визначеному напрямі [4, с. 90].

На нашу думку, виникнення i задоволення рекреаційних потреб відбувається на циклічно-синергетичній основі. Стійка комбінація повторюваних рекреаційних занять за певний відрізок часу дістала назву циклу рекреаційної діяльності (ЦРД) своєрідної програми відпочинку, яка дозволяє реалізувати певні рекреаційні цілі, мотивації і вимоги рекреантів у конкретних умовах. Кожна людина самостійно несвідомо конструює ЦРД, виходячи 3 власних уявлень про корисність і атрактивність рекреаційної діяльності, звичок, моди, цін, грошових доходів та інших чинників [5, с. 18]. Стримуючими факторами при цьому можуть виступати значні відстані, культурна дистанція, висока вартість мандрівок, незадовільна якість обслуговування, ефект сезонності тощо.

Передусім, на формування рекреаційних потреб впливає велике розмаїття соціально-економічних, демографічних, особистісно-поведінкових, ресурсно-екологічних, політичних та інших чинників. Це своєрідні флуктуаційні впливи, які відхиляють туристично-рекреаційну галузь від закономірних шляхів еволюції, однак у певний момент один з цих впливів трансформується у потужний атрактор, який задає нову траєкторію розвитку системи. Кардинальні зміни у вподобаннях і можливостях рекреантів (зокрема, під впливом пандеміі) асоціюються 3 так званими точками біфуркації, проходження яких може принципово змінювати усталені набори рекреаційних занять. Новими атракторами еволюції рекреаційних потреб у географічному контексті стають території, безпечні для відвідування в умовах пандемії, у фінансовому - прагнення отримати максимум 
вражень від відпочинку 3 мінімальними витратами, у технологічному - поширення «віртуальних подорожей» завдяки розвитку сучасних комп'ютерних технологій.

Цикли рекреаційної діяльності, у свою чергу, дозволяють зрозуміти логіку функціонування ринку туристичних і рекреаційних послуг, в траєкторії розвитку якого спостерігаються як біфуркаційні зони імовірнісного розвитку (моменти перелому тенденцій циклу), так і більш стійкі і передбачувані для планування періоди.

Кожен рекреаційний цикл має власну ритміку і просторовий механізм саморегуляції. Чим більше варіантів комбінування елементарних рекреаційних занять, тим ефективнішою $\epsilon$ рекреаційна діяльність, оскільки при цьому в одиницю часу задовольняється більше рекреаційних потреб [6, с. 20]. Але для запобігання некерованому хаосу самоорганізаційні тенденції повинні гармонійно сполучатися з управлінськими (організаційними) впливами, що обумовлює потребу в усвідомленій підтримці державою туристично-рекреаційної галузі. Зокрема, держава субсидіює будівництво різних споруд для відпочинку, що створює умови для проведення відпустки певних соціальних груп - молоді, багатодітних сімей, людей похилого віку та 3 обмеженими можливостями тощо [7, с. 56].

Таким чином, рекреаційні цикли формуються у нелінійному середовищі, окремі елементи якого можуть виконувати роль як потужних атракторів розвитку туристично-рекреаційної галузі, так i невпорядкованих флуктуаційних впливів, які привносять елементи невизначеності (хаосу) і порушують плани суб'єктів рекреаційної діяльності. Втім, флуктуації виконують інноваційну функцію, змушуючи вести пошук інноваційних підходів до задоволення мінливих потреб туристів і рекреантів.

Одним 3 критеріїв успішності функціонування туристичнорекреаційної галузі пропонуємо вважати досягнення ефекту синергії, що передбачає одночасне стрибкоподібне збільшення соціальних та економічних ефектів і не менш стрімке зниження рекреаційного навантаження на природний комплекс (рис. 1). 


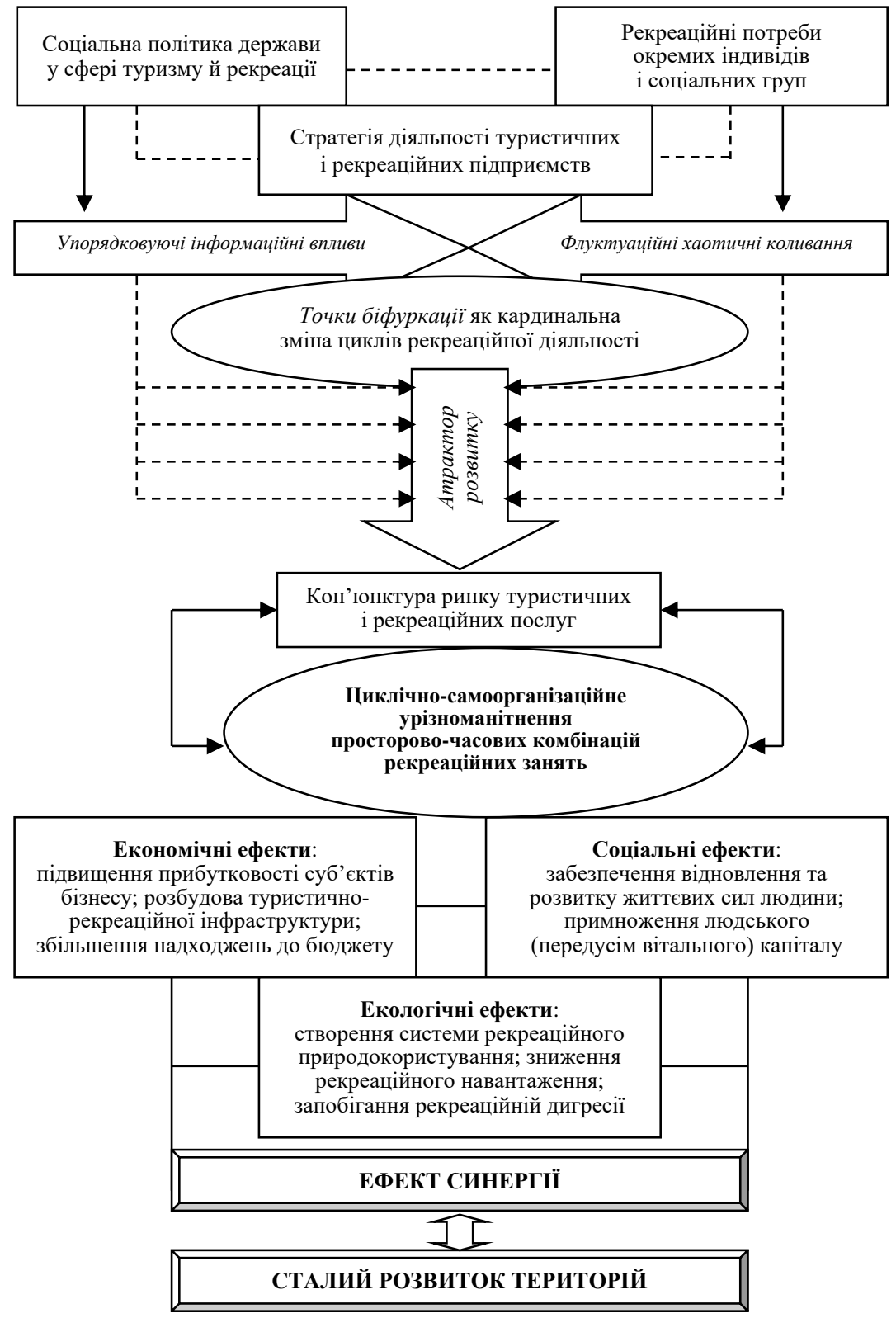

Рис. 1. Прояви синергетичної самоорганізації у функціонуванні ринку туристичних і рекреаційних послуг 
Такий підхід корелює зі стратегією сталого розвитку території, що грунтується на синтезі трьох компонент: економічної (оптимальне використання туристично-рекреаційних ресурсів); соціальної (примноження людського капіталу, збереження стабільності суспільних і культурних систем); екологічної (забезпечення цілісності біологічних і фізичних природних систем).

Загалом, синергетичний підхід орієнтує на урізноманітнення просторово-часових комбінацій рекреаційних занять, що дозволить підвищити роль рекреації у процесах відтворення людського капіталу (соціальний аспект), розвитку туристичної сфери (комерційний аспект) та раціонального природокористування (екологічний аспект).

\section{Література:}

1. Кунгурцева-Мащенко Т.Є. Синергетичний ефект у діяльності курортнорекреаційних систем в умовах інтеграційного розвитку. Глобальні та національні проблеми економіки: електронне наукове фахове видання. 2018. Вип. 23. С. 706-709. URL: http://global-national.in.ua/archive/23-2018/136.pdf (дата звернення: 21.01.2021).

2. Моісєєва Н.І. Інноваційність туристичної сфери регіону в умовах сталого розвитку: стратегічний вимір: автореф. дис. ... докт. екон. наук: 08.00.05 «Розвиток продуктивних сил та регіональна економіка». Одеса, 2019. 43 с.

3. Скоробогатова Т.Н. Образование синергетического эффекта в туризме как результат функционирования логистических сервисных систем. Вісник економічної науки Украӥни. 2013. № 1. С. 164-167.

4. Шарко М.В., Шмулевич П.В. Использование синергии в сфере туризма. Інфраструктура ринку. 2017. Вип. 11. С. 87-92. URL: http://www.market-infr.od.ua/journals/2017/11_2017_ukr/17.pdf (дата звернення: 21.01.2021).

5. Чир Н.В. Рекреаційна географія: навчально-методичний посібник. Мукачево : вид-во Дишкант С.Я., 2019. 156 с.

6. Величко В.В. Організація рекреаційних послуг: навчальний посібник. Харків : Харківський національний університет міського господарства ім. О.М. Бекетова, 2013. 202 с.

7. Роїк О.Р. Вплив соціальної політики на розвиток туризму в умовах формування інноваційної економіки в Україні. Причорноморські економічні студіï. 2016. Вип. 10. С. 53-57. 